\title{
Microbiological and Nutritional Quality Characteristics of Kunu Drinks Sold in Calabar Metropolis
}

\author{
Asuquo NE, Antai SP and Tiku DR* \\ Department of Microbiology, University of Calabar, Nigeria
}

Submission: October 30, 2017; Published: December 08, 2017

*Corresponding author: Tiku DR, Department of Microbiology, University of Calabar, P.M.B 1115, Cross river state, Nigeria, Email: dominicreuben@yahoo.com

\begin{abstract}
The study was aimed at investigating the microbiological and nutritional quality of kunu drinks sold in selected markets in Calabar metropolis. The research was undertaken within a period of six months. Standard microbiological methods were used to isolate, characterize and identify microbial isolates from the collected kunu samples. The mean bacterial count of the analysed kunu samples ranged between $40.0 \pm 0.15 \times 10^{7} \mathrm{cfu} /$ $\mathrm{ml}$ (samples from Bogobiri) to $53.6 \pm 0.04 \times 10^{7} \mathrm{cfu} / \mathrm{ml}$ (samples from Marian market), the mean coliform count of the samplesranged between $39.5 \pm 0.07 \times 10^{7} \mathrm{cfu} / \mathrm{ml}$ (samples from Bogobiri) to $48.3 \pm 0.85 \times 10^{7} \mathrm{cfu} / \mathrm{ml}$ (samples from Marian market), while the fungal load of the analysed samples ranged between $38.0 \pm 0.26 \times 10^{7} \mathrm{cfu} / \mathrm{ml}$ (samples from Bogobiri) to $72.0 \pm 0.27 \times 10^{7} \mathrm{cfu} / \mathrm{ml}$ (samples from Watt market). Bacteria genera isolated from the samples were identified as Pseudomonas spp, Staphylococcus spp, Bacillus spp and Escherichia coli, while fungi isolated from the samples were identified as Aspergillus spp, Penicillium spp, Fusarium spp, and Saccharomyces cerevisae. Staphylococcus spp had the highest percentage occurrence (35.71\%) compared to other bacterial isolates obtained from the analysed kunu samples; while Aspergillus spp had the highest percentage occurrence (37.5\%) compared to other fungi isolates obtained from the analysed kunu samples. The nutritional quality of the analysed kunu samples revealed that the physiochemical content of the samples varied from pH $(3.73 \pm 0.01$ to $4.00 \pm 0.01)$, ash content $(0.45 \pm 0.01 \%$ to $1.64 \pm 0.01 \%)$, moisture content ( $50.02 \pm 0.01 \%$ to $69.60 \pm 0.01 \%$ ), crude fibre $(8.72 \pm 0.01 \%$ to $14.00 \pm 0.01 \%)$, fat content $(0.61 \pm 0.02 \%$ to $2.02 \pm 0.01 \%)$, protein content $(7.02 \pm 0.03 \%$ to $18.73 \pm 0.04 \%)$, total carbohydrate $(9.09 \pm 0.01 \%$ to $23.38 \pm 0.02 \%)$ and titrateable acidity $(4.20 \pm 0.02 \%$ to $7.8 \pm 0.01 \%)$.

The result of mineral content analysis of the kunu samples ranged between $16.52 \mathrm{mg} / \mathrm{l}-21.62 \mathrm{mg} / \mathrm{l}$ for Ca, $26.21 \mathrm{mg} / \mathrm{l}-56.50 \mathrm{mg} / \mathrm{l}$ for Fe, $23.63 \mathrm{mg} / \mathrm{l}-42.50 \mathrm{mg} / \mathrm{l}$ for $\mathrm{Na}$ amongst others. The concentrations of zinc, copper, lead and cadmium found in the kunu samples were within permissible limits (Zinc- $99.0 \mathrm{mg} / \mathrm{kg}$, Copper- $40.0 \mathrm{mg} / \mathrm{kg}$, Lead- $0.30 \mathrm{mg} / \mathrm{kg}$ and Cadmium- $0.20 \mathrm{mg} / \mathrm{kg}$ ) set by FAO/WHO guidelines for food standard. The result of the toxicant analysis revealed the absence of mercury, cadmium and lead in the analysed kunu samples. However, this study has revealed that the microbiological quality of the analysed kunu samples was below acceptable standards and unfit for human consumption. There is the need for adequate hygienic conditions during processing and preparation of this beverage so as to curb or reduce potential public health risk associated with consumption of food contaminated with/by food borne pathogens.
\end{abstract}

\section{Introduction}

Kunu is a traditionally fermented non-alcoholic beverage consumed by a large population in Nigeria and by mostly the northerners. It is popular mainly because of its thirst quenching properties [1,2]. The preparation protocol of kunu varies amongst people and can generally be produced from either of the following substrates; millet (Pennisetumtyphoideum), maize (Zea mays), or sorghum (sorghum bicolor), but millet is the most common substrate [3]. Spices such as ginger, black pepper, red pepper, cloves and sugar are commonly added as flavor and taste improver [4]. Kunu plays a vital role in the dietary pattern of the people in developing countries like Nigeria [5], and has been shown to contain carbohydrates, vitamins and minerals but low in protein [6] although sorghum made kunu contains starch, protein, fat, fiber and ash along with a wide array of amino acids. It is believed to be of immense social, economic, nutritional, and medicinal importance to consumers [7].

The traditional production of kunu is still on primitive technology and as such production protocol is not standardized. Generally, the process of preparation involves wet milling of cereal grains with spices, wet sieving and partial gelatinization of the curry, sugar addition, bottling and sales. Tastes and cultural habits make for the variation in the method of preparation and partly explains the lack of consistency in product quality [1]. 
Kunuis liable to microbial spoilage if not adequately stored and could act as important medium for transmission of pathogenic micro-organisms. Many organisms can use the carbohydrate content for fermentation processes producing undesirable changes in them. Researchers have reported that a large number of lactic acid bacteria, coliforms, moulds, and yeast are involved in food spoilage which in turn causes intoxication in man [8] and local beverage drinks may be the common sources of infection. The consumption of these local drinks is of public health significance, hence local drinks may serve as vehicles for zoonotic and food borne diseases or pathogens such as Staphylocosis, Salmonellosis, Brucellosis, Shigellosis, Escherichia coli infection, etc [9]. It was therefore necessary for this study to focus on investigating the microbiological and nutritional quality characteristics of kunu samples sold in Calabar metropolis.

\section{Materials and Methods}

\section{Collection of samples}

Two samples each of hawked kunu drinks were purchased from five locations in Calabar metropolis namely; Watt market, Akim market, Army barracks, Bogobiri and Marian market. The samples were properly labelled, placed in plastic containers and transported to the department of Microbiology laboratory, University of Calabar for analysis.

\section{Media used}

The media used in this work were; nutrient, sugar, MaCconkey agar, sabouroud dextrose agar, kliger iron agar, and Simon's citrate agar. All the media were product of Diagnostic Laboratory Ltd, USA and they were all prepared in accordance to manufacturer's instructions.

\section{Microbiological analysis}

Ten (10) ml of the kunu samples were aseptically transferred into $90 \mathrm{ml}$ of sterile distilled water in a $100 \mathrm{ml}$ conical flask. The samples were vortexed to homogenize and allowed to stand for 10 minutes. From the initial dilution, 10-fold serial dilutions were carried out in clean sterile test tubes containing $9 \mathrm{ml}$ of sterile distilled water.

\section{Plating procedures}

$0.1 \mathrm{ml}$ of desired dilutions $10^{-3}-10^{-5}$ were spread plated in triplicates onto nutrient agar, MaCconkey agar, Sabouroud dextrose agar. The nutrient agar and MaCconkey agar plates were then incubated at $37^{\circ} \mathrm{C}$ for $24 \mathrm{hrs}$ for bacterial and coliform counts, while the Sabouroud dextrose agar plates were incubated at $35{ }^{\circ} \mathrm{C}$ for $48-72$ hours for fungi count.

\section{Purification of isolates}

Following enumeration of total bacterial, coliform and fungal counts, colonies were picked at random and sub-cultured for purification onto nutrient agar (bacteria), Macconkey agar (coliform) and Sabouroud dextrose agar (fungi). Purified isolates were stocked in appropriate media for further studies.

\section{Identification and characterization of isolates}

Purified isolates were characterized by gram morphology and biochemical test using Bergey's manual of determinative bacteriology $[10,11]$, while fungi isolates were identified by cultural and morphological characteristics as described by Barnett [12].

\section{Determination of Proximate Composition of Cereal Foods and Drinks}

\section{pH determination}

The method of A.O.A.C. [13] was used. The $\mathrm{pH}$ meter was first standardized with a buffer solution of $\mathrm{pH} 7.0$ so as to calibrate the $\mathrm{pH}$ meter. The samples were measured out in a beaker and the electrode was rinsed with distilled water before dripping it into the kunu samples and the result obtained was recorded.

\section{Ash content determination}

The method described by James [14] was used. Ten (10) ml of the beverage sample was measured into a previously weighed porcelain crucible. This was placed in a muffle furnace and heated at $550{ }^{\circ} \mathrm{C}$ for $2 \mathrm{hrs}$. The ashing continued until all the samples became completely ash. The crucible and its content were cooled in a dessicator and re-weighed. The percentage ash was calculated.

$$
\begin{gathered}
\% \text { Ash }: \frac{W_{2}-W_{1}}{W_{3}} \times \frac{100}{1} \\
\text { Where, } \mathrm{W}_{2}=\text { Weight of sample +crucible } \\
\mathrm{W}_{3}=\text { Weight of empty crucible } \\
\mathrm{W}_{1}=\text { Weight of sample used }
\end{gathered}
$$

\section{Determination of moisture content}

The method of Pearson [15] was used. The weight of an empty aluminum dish can $\left(\mathrm{W}_{0}\right)$ was determined before the sample was introduced into it. About $20 \mathrm{mls}$ of the kunu sample was measured out and further weighed $\left(\mathrm{W}_{1}\right)$ in the aluminum dish can. The aluminum dish can was then dried in a hot air oven for $24 \mathrm{hrs}$ and cooled in a dessicator. The final weight $\left(\mathrm{W}_{2}\right)$ was determined.

Percentage of moisture content was determined as follows:

Percentage of moisture content $=\frac{\left(W_{1}-W_{0}\right)-\left(W_{2}-W_{0}\right)}{\left(W_{1}-W_{0}\right) \times 100}$

Where, $\mathrm{W}_{0}=$ Weight of empty moisture can

$$
\mathrm{W}_{1}=\text { Weight of moisture can and sample }
$$

$\mathrm{W}_{2}=$ Weight of desiccated sample

$\left(\mathrm{W}_{1}-\mathrm{W}_{0}\right)-\left(\mathrm{W}_{2}-\mathrm{W}_{0}\right)=$ Weight loss

$\left(\mathrm{W}_{1}-\mathrm{W}_{0}\right)=$ Weight of sample.

\section{Determination of crude fiber content}

The method reported by James [13] was used where $20 \mathrm{mls}$ of sample was weighed into a 1 liter conical flask and the weight 
$\left(\mathrm{W}_{0}\right)$ noted. Then $200 \mathrm{mls}$ of boiling $1.25 \%$ Tetraoxosulphate VI $\left(\mathrm{H}_{2} \mathrm{SO}_{4}\right)$ was added into the conical flask containing the sample and boiled gently for 30 minutes. The content was filtered through a muslin cloth and the residue scraped into a clean conical flask using a spatula. Then $20 \mathrm{mls}$ of boiling $1.25 \%$ sodium chloride $(\mathrm{NaOH})$ was added and allowed to boil gently for 30 minutes. Further filtration was carried out using the Buckner pressurized filter through a muslin cloth spread over its funnel. The resulting residues was thoroughly washed with distilled water and rinsed with 10\% hydrochloric acid (HCL) and twice with ethanol. Final rinsing with petroleum ether was repeated three times and allowed to drain. The residue was scraped into a flat silica dish and dried overnight in the oven at $105^{\circ} \mathrm{C}$. Thereafter, it was cooled in the dessicator and the sample was weighed $\left(\mathrm{W}_{1}\right)$. The sample was further ashed at $55^{\circ} \mathrm{C}$ for 90 minutes in a muffle furnace, cooled again in the dessicator and reweighed. Percentage fiber content was determined as follows:

Percentage fiber content $=\frac{\left(W_{1}-W_{2}\right)}{W_{0} \times 100}$

Where, $\mathrm{W}_{0}=$ Weight of sample

$\mathrm{W}_{1}=$ Weight of insoluble material

$\mathrm{W}_{2}=$ Weight of ash

\section{Determination of lipid content}

The method reported by James [13] was used. A $250 \mathrm{ml}$ round bottom flask was dried in an oven, allowed to cool in the dessicator and the weight measured. Two hundred (200) $\mathrm{ml}$ of petroleum ether was introduced into the dry $250 \mathrm{ml}$ round bottom flask on the hot water bath of the soxhlet extracting unit. The content of round bottom flask was then heated. As the ether evaporated, its condensed dropped into the thimble where it extracted the ether soluble constituent into the round-bottom flask. The extraction lasted for 5-6 hours during which all the petroleum ether moved up to the extractor, leaving behind the fats in the round bottom flask. The porous thimble was removed with care and the petroleum ether collected from the top for reuse. The round bottom flask containing the lipids was then removed and oven dried for 1 hour at $105{ }^{\circ} \mathrm{C}-110{ }^{\circ} \mathrm{C}$. After drying, it was further transferred into a dessicator (containing silica gel) to cool and then re-weighed.

Percentage of lipid content $=\frac{\left(W_{3}-W_{2}\right)}{W_{1}-W_{0}} \times \frac{100}{1}$

Where, $\mathrm{W}_{0}=$ Weight of empty porous thimble

$\mathrm{W}_{1}=$ Weight of thimble and sample

$\mathrm{W}_{2}=$ Weight of empty extraction flask

$\mathrm{W}_{3}=$ Weight of extraction flask and extract

$\mathrm{W}_{1}-\mathrm{W}_{0}=$ Weight of sample

$\mathrm{W}_{3}-\mathrm{W}_{2}=$ Weight of extract

\section{Determination of protein content}

Twenty (20) mls of each sample was digested with $30 \mathrm{ml}$ of concentrated sulphuric acid using $2 \mathrm{~g}$ of copper sulphate and
$16.0 \mathrm{~g}$ of sodium sulphate salt until a clear green solution was obtained. This was dissolved in distilled water and made up to $100 \mathrm{ml}$ in a volumetric flask. $12.5 \mathrm{ml}$ of the digest was measured into a semi-micro kjeldhal Markham distillation apparatus and treated with $12.5 \mathrm{ml}$ of $1.25 \%$ of sodium hydroxide $(\mathrm{NaOH})$ solution. This was distilled with $10 \mathrm{ml}$ of boric acid double indicator. The distillate was then titrated with $0.1 \%$ HCL solution until a light pink end-point was reached. Blank titration was also carried out in similar manner. Distillation was carried out in triplicates and the percentage nitrogen was obtained by appropriate calculation.

$\%$ Nitrogen $(\mathrm{w} / \mathrm{w}$ in sample $)=$

ml of Hcl(sample $)-m l$ of HCL (blank) $\times$ molarity of $H C L \times 100 g \times 100 \times 14$ Weight of sample $x \mathrm{ml}$ of digest $\times 1000$

The crude protein was obtained by multiplying the percentage nitrogen by 6.25 .

\section{Determination of carbohydrate content}

The method [16] was used. Carbohydrate content was determined indirectly by subtracting the crude protein, crude fiber, lipid, ash, and moisture content from $100 \%$ as follows:

Percentage carbohydrate content $(\% \mathrm{CC})=100-(\%$ protein + $\%$ fiber + \%ash + \%moisture + \%lipid) .

\section{Determination of mineral content}

The dry ashing procedure was used for mineral content determination. Twenty (20) mls of each sample was accurately weighed into porcelain crucibles and pre-ashed until the sample was completely charred on hot plate. The pre-ashed samples were thereafter ashed in the muffle furnace at $500{ }^{\circ} \mathrm{C}$ till the ash was white for about 2 hours, after ashing, the crucibles were transferred into the dessicator to cool and then reweighed. Each sample was quantitatively transferred into volumetric flasks by carefully washing the crucibles with $1.0 \mathrm{ml}$ nitric acid, then with portions of dilute nitric acid.

All washings were transferred to individual volumetric flasks after the second washing procedure. The solutions were diluted to volume with deionized water, and were used for individual mineral determination using the appropriate standards and blank. The mineral content of the kunu drinks sampled were determined with the Atomic Absorption Spectrophotometer [12].

\section{Result}

Microbial load of collected kunu samples are presented in Table 1-3. It showed that the mean bacterial count of the sample ranged between $40.0 \pm 15 \times 107 \mathrm{cfu} / \mathrm{ml}$ (samples from Bogobiri) to $53.6 \pm 0.04 \times 107 \mathrm{cfu} / \mathrm{ml}$ (samples from Marian market) (Table 1). The coliform count of the samples ranged between $39.5 \pm 0.07 \times 107 \mathrm{cfu} / \mathrm{ml}$ (samples from Bogobiri) to $48.3 \pm 0.85 \times 107 \mathrm{cfu} / \mathrm{ml}$ (samples from Marian market) (Table 2) while the fungal load of samples ranged between $38.0 \pm 0.26 \times 107 \mathrm{cfu} / \mathrm{ml}$ (samples from Bogobiri) to $72.0 \pm 0.27 \times 107 \mathrm{cfu} / \mathrm{ml}$ (samples from Watt market) (Table 3 ). 
Table 1: Mean total bacteria count of kunu samples.

\begin{tabular}{|c|c|c|}
\hline Sample & Location & $\begin{array}{c}\text { Mean Total Bacteria } \\
\text { Count (Cfu/Ml) }\end{array}$ \\
\hline Kunu & Bogobiri & $40.0 \pm 0.05 \times 107$ \\
\hline & Watt market & $50.0 \pm 0.06 \times 107$ \\
\hline & Akim market & $50.44 \pm 0.15 \times 107$ \\
\hline & Army barracks & $47.2 \pm 0.21 \times 107$ \\
\hline & Marian market & $53.6 \pm 0.04 \times 107$ \\
\hline
\end{tabular}

Table 2: Mean coliform count of kunu samples.

\begin{tabular}{|c|c|c|}
\hline Sample & Location & $\begin{array}{c}\text { Mean Total Bacteria } \\
\text { Count (Cfu/Ml) }\end{array}$ \\
\hline Kunu & Bogobiri & $39.5 \pm 0.07 \times 107$ \\
\hline & Watt market & $41.5 \pm 0.05 \times 107$ \\
\hline & Akim market & $40.3 \pm 0.05 \times 107$ \\
\hline & Army barracks & $42.3 \pm 0.04 \times 107$ \\
\hline & Marian market & $48.3 \pm 0.85 \times 107$ \\
\hline & \multicolumn{2}{|c}{} \\
\hline
\end{tabular}

Table 3: Mean fungal count of kunu samples.

\begin{tabular}{|c|c|c|}
\hline Sample & Location & $\begin{array}{c}\text { Mean Total Bacteria } \\
\text { Count (Cfu/Ml) }\end{array}$ \\
\hline Kunu & Bogobiri & $38.0 \pm 0.26 \times 107$ \\
\hline & Watt market & $72.0 \pm 0.27 \times 107$ \\
\hline & Akim market & $66.0 \pm 0.15 \times 107$ \\
\hline & Army barracks & $52.0 \pm 0.13 \times 107$ \\
\hline & Marian market & $58.0 \pm 0.25 \times 107$ \\
\hline
\end{tabular}

\section{Biochemical characterisation and identification of isolates}

Bacterial genera identified from the kunu samples were; Pseudomonas spp, Staphylococcus spp, Bacillus spp, and Escherichia coli, while fungi genera identified were Aspergillus spp, Penicillium spp, Fusarium spp, and Saccharomyces cerevisae.

\section{Frequency and percentage occurrence of isolates}

Figure $1 \& 2$ presents the results of frequency and percentage occurrence of bacteria and fungi isolates from the analysed kunu samples. It showed that Staphylococcus spp had the highest percentage occurrence (35.71\%) compared to other bacteria isolates (Figure 1). Aspergillus spp had the highest percentage occurrence $(37.50 \%)$ compared to other fungi isolates (Figure 2).

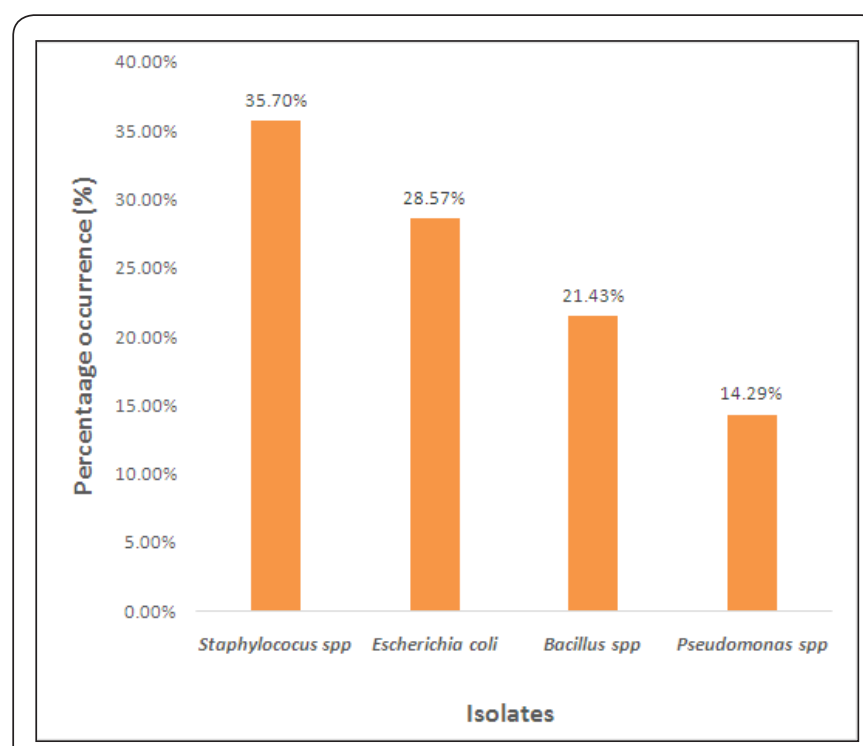

Figure 1: Percentage occurrence of bacteria isolates from kunu samples collected from five locations in Calabar Metropolis.

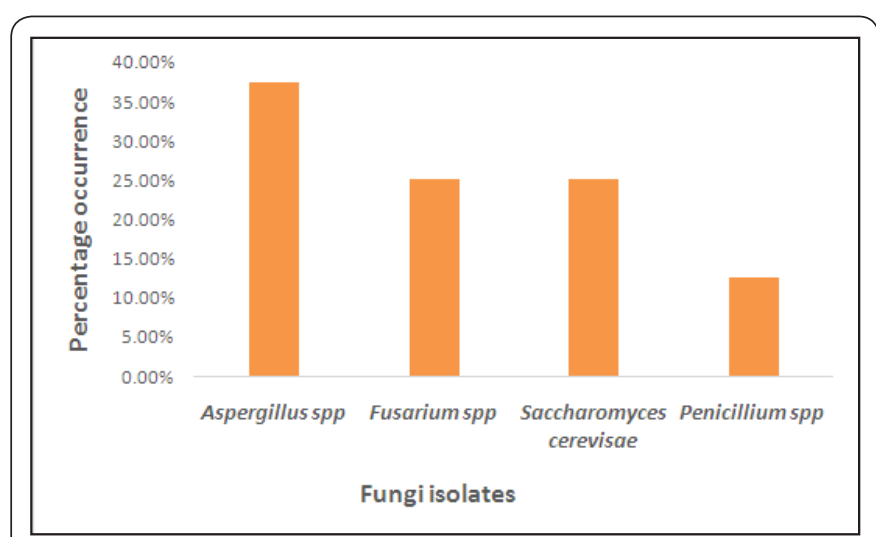

Figure 2: Percentage occurrence of fungi isolates from kunu samples collected from five locations in Calabar Metropolis.

Table 4: Proximate composition of kunu drinks sold in selected locations within Calabar metropolis.

\begin{tabular}{|c|c|c|c|c|c|c|c|}
\hline Sample & pH & $\begin{array}{c}\text { Ash Content } \\
\%\end{array}$ & $\begin{array}{c}\text { Moisture } \\
\text { Content } \%\end{array}$ & $\begin{array}{c}\text { Crude Fibre } \\
\%\end{array}$ & $\begin{array}{c}\text { Fat } \\
\text { Content \% }\end{array}$ & $\begin{array}{c}\text { Protein } \\
\text { Content \% }\end{array}$ & $\begin{array}{c}\text { Total } \\
\text { Carbohydrate } \\
\%\end{array}$ \\
\hline Acidity \% \\
\hline Bogobiri & $3.73 \pm 0.01$ & $0.92 \pm 0.04$ & $50.20 \pm 0.01$ & $14.00 \pm 0.001$ & $1.35 \pm 0.02$ & $10.15 \pm 0.06$ & $23.38 \pm 0.05$ \\
\hline Watt market & $3.63 \pm 0.01$ & $1.64 \pm 0.02$ & $53.60 \pm 0.00$ & $13.00 \pm 0.001$ & $0.61 \pm 0.00$ & $18.73 \pm 0.04$ & $12.42 \pm 0.24$ \\
\hline Akim market & $3.80 \pm 0.01$ & $1.46 \pm 0.01$ & $54.10 \pm 0.00$ & $11.02 \pm 0.00$ & $1.72 \pm 0.01$ & $10.33 \pm 0.02$ & $21.37 \pm 0.03$ \\
\hline
\end{tabular}


Advances in Biotechnology \& Microbiology

\begin{tabular}{|c|c|c|c|c|c|c|c|c|}
\hline $\begin{array}{c}\text { Army } \\
\text { Barracks }\end{array}$ & $3.51 \pm 0.00$ & $0.62 \pm 0.01$ & $69.60 \pm 0.00$ & $09.51 \pm 0.00$ & $1.28 \pm 0.01$ & $7.02 \pm 0.03$ & $11.97 \pm 0.02$ & $7.30 \pm 0.03$ \\
\hline $\begin{array}{c}\text { Marian } \\
\text { market }\end{array}$ & $4.00 \pm 0.01$ & $0.45 \pm 0.01$ & $66.30 \pm 0.02$ & $8.72 \pm 0.01$ & $2.02 \pm 0.01$ & $12.60 \pm 0.04$ & $9.09 \pm 0.01$ & $12.61 \pm 0.02$ \\
\hline
\end{tabular}

Values are means of triplicate determinations \pm standard deviation. $L S D=11.91$. Means followed by similar superscripts within the same row are not significantly $(P<0.05)$ different according to LSD test.

Table 5: Elemental analysis of Kunu drinks sold locally in selected locations in Calabar metropolis.

\begin{tabular}{|c|c|c|c|c|c|c|c|c|c|c|}
\hline Locations & $\mathbf{C a}$ & $\mathbf{F e}$ & $\mathbf{M g}$ & $\mathbf{M n}$ & $\mathbf{Z n}$ & $\mathbf{P b}$ & $\mathbf{C u}$ & $\mathbf{H g}$ & $\mathbf{C d}$ & $\mathbf{N a}$ \\
\hline Bogobiri & $17.63 \pm 0.01$ & $53.2 \pm 0.01$ & $31.2 \pm 0.03$ & $0.36 \pm 0.01$ & $44.1 \pm 0.05$ & $\mathrm{ND}$ & $0.02 \pm 0.03$ & $\mathrm{ND}$ & $\mathrm{ND}$ & $33.22 \pm 0.06$ \\
\hline Watt market & $12.46 \pm 0.03$ & $56.5 \pm 0.20$ & $12.2 \pm 0.01$ & $0.41 \pm 0.03$ & $43.21 \pm 0.04$ & $\mathrm{ND}$ & $0.03 \pm 0.01$ & $\mathrm{ND}$ & $\mathrm{ND}$ & $30.11 \pm 0.04$ \\
\hline Akim market & $17.55 \pm 0.03$ & $26.21 \pm 0.12$ & $22.62 \pm 0.12$ & $0.33 \pm 0.02$ & $25.88 \pm 0.11$ & $\mathrm{ND}$ & $0.32 \pm 0.02$ & $\mathrm{ND}$ & $\mathrm{ND}$ & $42.5 \pm 0.06$ \\
\hline $\begin{array}{c}\text { Army } \\
\text { Barracks }\end{array}$ & $21.62 \pm 0.01$ & $38.42 \pm 0.01$ & $31.61 \pm 0.01$ & $0.51 \pm 0.01$ & $42.42 \pm 0.01$ & $\mathrm{ND}$ & $0.27 \pm 0.01$ & $\mathrm{ND}$ & $\mathrm{ND}$ & $23.63 \pm 0.01$ \\
\hline $\begin{array}{c}\text { Marian } \\
\text { market }\end{array}$ & $16.52 \pm 0.01$ & $46.88 \pm 0.01$ & $24.55 \pm 0.01$ & $0.44 \pm 0.01$ & $23.25 \pm 0.01$ & $\mathrm{ND}$ & $0.33 \pm 0.01$ & $\mathrm{ND}$ & $\mathrm{ND}$ & $25.33 \pm 0.01$ \\
\hline & & & & & & & & & \\
\hline
\end{tabular}

ND $=$ Not Detected

\section{Proximate composition of collected kunu samples}

Table 4 presents the result of proximate composition of the analysed kunu samples. It showed that the proximate composition of the analysed kunu samples ranged between $\mathrm{pH} \quad(4.64 \pm 0.01 \%-3.73 \pm 0.01 \%)$ ash content $(1.64 \pm 0.01 \%$ $0.45 \pm 0.01 \%)$, moisture content $(69.6 \pm 0.01 \%$ to $50.20 \pm 0.01 \%)$, crude fibre (14.00 $\pm 0.01-8.72 \pm 0.01 \%)$, fat content $(2.02 \pm 0.02 \%$ $0.61 \pm 0.01 \%)$, protein content $(18.73 \pm 0.03 \% 7.02 \pm 0.04 \%)$, total carbohydrate $(23.38 \pm 0.01 \%-9.9 \pm 0.02 \%)$ and titratable acidity $(7.8 \pm 0.01 \%-4.2 \pm 0.02 \%)$.

\section{Mineral content analysis}

Table 5 shows the result of the mineral content analysis of the kunu samples. It was showed that the concentration of the mineral content in the kunu samples ranged from $12.46 \mathrm{mg} / \mathrm{l}$ $17.65 \mathrm{mg} / \mathrm{l}(\mathrm{Ca}), 26.21 \mathrm{mg} / \mathrm{l}-56.50 \mathrm{mg} / \mathrm{l}(\mathrm{Fe}), 12.20 \mathrm{mg} / \mathrm{l}-31.61 \mathrm{mg} /$ $\mathrm{l}(\mathrm{Mg}), 23.63 \mathrm{mg} / \mathrm{l}-42.5 \mathrm{mg} / \mathrm{l}(\mathrm{Na})$ and $23.25 \mathrm{mg} / \mathrm{l}-44.10 \mathrm{mg} / \mathrm{l}(\mathrm{Zn})$. The lowest mineral content values were observed in $\mathrm{Mn}$ and $\mathrm{Cu}$ with a range of $0.33 \mathrm{mg} / \mathrm{l}-0.510 \mathrm{mg} / \mathrm{l}$ and $0.02 \mathrm{mg} / \mathrm{l}-0.33 \mathrm{mg} / \mathrm{l}$ respectively. $\mathrm{Pb}, \mathrm{Hg}$ and $\mathrm{Cd}$ were not detected at all in the kunu samples analysed.

\section{Discussion}

A higher microbial count was observed in the analysed kunu samples, this was not surprising as the kunu production systems are sometimes done under unhygienic conditions [17], with no authorized agency to monitor their microbial quality and safety. The occurrence of Staphylococcus spp, Fusarium spp, Penicillium spp, and Saccharomyes cerevisae in the analyzed kunu samples was not surprising as it corroborates with the study of Ayandele [17]; who reported the isolation of S. aureus, S. pyogenes, P. aeruginosa, A. flavus, Rhizopus spp, Bacillus subtilis, Proteus spp, and S. cerevisae in hawked kunu and zobo drinks sold within LAUTECH campus, Ogbomoso. Similar study by Innocent
[18] reported the isolation of Escherichia coli, Staphylococcus aureus, Salmonella spp and Shigella spp in kunu-zaki sold in Maiduguri Metropolis. The organisms isolated from the analysed kunu samples are known to be important food borne pathogens.

Staphylococcus spp had the highest percentage of occurrence (35.71\%) and are however known to produce intoxication risk [19] and this makes their presence in the analyzed kunu samples worrisome. Staphylococcus aureus are found on the skin as normal flora of humans, but in situations where there is laxity in hygiene, their high load on products handled by man becomes un-surprising [20]. Noted that dissemination of Staphylococcus aureus from humans to food can occur by direct contact, indirectly by skin fragments or through respiratory tract droplet nuclei. Escherichia coli also had a high percentage occurrence (28.57\%), compared to other bacteria isolates identified in the analysed kunu samples. Their presence is an indication of faecal and environmental contamination and a signal of the presence of other enteric pathogens which may have occurred probably through the use of contaminated water, utensils [21]. The presence of Bacillus spp is also of public health threat, as they can produce toxins that cause pneumonia and beside this, they are known to produce heat resistant spores that cannot be eliminated by boiling [19]. The presence of Pseudomonas spp in the kunu samples could also be due to contaminated water used in the preparation of the drink.

Aspergillus spp had the highest frequency occurrence (37.50\%) compared to other fungi isolated in the analysed kunu samples. Their presence, as well as that of Penicillium spp, Saccharomyes cerevisae, and Fusarium spp in the kunu drinks may be linked to contamination through air or dust, contaminated packaging material or poor hygiene and sanitation of the processing environment [22]. Their presence is worrisome as some of these fungi can produce mycotoxins which can cause mycotoxicosis in humans [23]. 
The proximate analysis of the analysed kunu samples revealed a low $\mathrm{pH}$ for the samples; this was not surprising as the acidity of kunu beverage has been reported by several researchers to be as a result of lactic acid production by some non-pathogenic bacteria during fermentation [22]. However, the values for $\mathrm{pH}$ (3.95-4.08) obtained in this research were in line with that obtained by Innocent $O$ [18] but lower than that obtained by Akoma 0 [3], and Adejuyitan J [1]. The moisture content results agree well with the observations of Barnett $\mathrm{H}$ [12] that analysed kunu made from maize but slightly lower than that reported by Adejuyitan J [1] and Amusa N [24]. Moisture content contributes significantly to the microbial flora of the food drink samples [25]. The protein content values of the analysed kunu drinks were observed to be highest in kunu from Watt market $(18.73 \%)$ and lowest in kunu from Army barracks $(7.02 \%)$. These values were found to be higher than that obtained for wet milled kunu by [1] and [25]. The percentage of crude fat obtained in this work is comparable to that obtained by Innocent $O$ [18] but quite higher than that reported by [1]. The disparities observed in the proximate composition indices of the analysed kunu samples from the different locations compared to those from other authors could be due to the non-standardized method of preparation of the beverage by the local people.

Mineral content analysis of the analysed kunu samples revealed that kunu samples obtained from Watt market had the highest Fe content while kunu samples from Bogobiri had the least content. $\mathrm{Cu}$ content compared to other kunu samples obtained from different locations. Recommended permissible limit of zinc, copper, lead, and Cadmium are $99.0 \mathrm{mg} / \mathrm{kg}, 40.0 \mathrm{mg} /$ $\mathrm{kg}, 0.30 \mathrm{mg} / \mathrm{kg}$ and $0.20 \mathrm{mg} / \mathrm{kg}$ respectively as set by FAO [26]. The concentrations of zinc, copper, lead and cadmium found in the kunu and soymilk samples were within permissible limits set by FAO/WHO guidelines for food standard while mercury, cadmium and lead were not detected as these metals are toxic, carcinogenic and mutagenic to humans. Therefore their absence shows that the drinks are not toxic but are safe for consumption. The various elements present in the analysed kunu samples showed that the elements present in the beverage were significantly $(\mathrm{P} \leq 0.05)$ different. Elements such as calcium, iron, magnesium, sodium, and copper which are essential micronutrients required for the growth and production of bones, hair, nerves, and teeth; activation of enzymes, formation of red blood cells, melanin pigment formation, growth of bones, hair, blood and teeth, hormones, blood circulation, cellular intergrity, energy production, muscle contraction, osmotic pressure, water balance and intracellular fluids in the body are essential for health and as such are part of all aspects of cellular function and are involved in structural components of human beings were present in the analysed kunu samples. The absence of toxic metals (lead, mercury and cadmium) in the analysed kunu samples is a clear indication that this locally made beverage is fit for human consumption.

\section{Conclusion}

The study has revealed that the microbial quality of kunu samples sold in different markets in Calabar Metropolis are of low standard and unfit for human consumption. It is therefore recommended that kunu producers and hawkers/sellers should maintain adequate hygienic conditions during processing and preparation of these beverages so as to curb or reduce potential public health risk associated with these food borne pathogens.

\section{References}

1. Adejuyitan J, Adelakun O, Popoola F (2008) Evaluating the quality characteristics of kunu produced by dry-milled sorghum. African Journal of Biotechnology 7(13): 2244-2247.

2. Gaffa T, Jodeani I, Nkama J (2002) Traditional production, consumption and storage of kunu; A non-alcoholic cereal beverage. Plant Foods Hum Nutr 57(1): 73-81.

3. Akoma O, Jiya E, Mishilia E (2006) Influence of malting on the nutritional characteristic of kunu-zaki. African Journal of Biotechnology 5(10): 996-1000.

4. Ahmed E, Musa N, Ngoddy P (2003) Sensory attributes of extruded cereal legumes blends for instant kunu-zaki beverage. Journal of Food Microbiology 12: 1-12.

5. Adeyemi I, Umar S (1994) Effect of method of manufacture on quality characteristics of kunu-zaki, millet based beverage. Nigerian Food Journal 12: 34-40.

6. Ayo J, Okaka C (1998) Interaction effects of Calabarfarinase extracts and $\mathrm{pH}$ level on some physiochemical properties of kunu-zaki. Proceedings of the $22^{\text {nd }}$ Annual NIFEST conference. $23^{\text {rd }}-26^{\text {th }}$ November, Abeokuta, Nigeria, pp. 31-33.

7. Effiuvwevwere B, Akoma O (1995) The microbiology of kunu-zaki, a cereal beverage from northern Nigeria during the fermentation process. World Journal of Microbial Biotechnology 11: 491-493.

8. Sperber W (2003) Food safety-future challenges. Food Control 14: 7374.

9. Amusa NA, Odumbako O, Ashaya A (2009) Microbiological and nutritional quality of hawked Kunu widely consumed in Nigeria. Journal of Food Microbiology 12: 1-11.

10. Holt J, Krery H, Sneal R, Williams S (1994) Bergey's manual of determinative bacteriology. $\left(8^{\text {th }}\right.$ edn), Williams and Wittkens Company Baltimore, USA, p. 111.

11. Cheesbrough M (2000) District Laboratory practice in tropical countries (part 2). Cambridge University press, London, England, pp. 132-134.

12. Barnett H, Hinter B (1972) Illustrated genera of imperfect fungi. Minneapolis publishing company, Minneapolis, US, pp. 241-250.

13. AOAC (1990) Official methods of Analysis. (1 $15^{\text {th }}$ edn), Association of official Analytical Chemist, Washington DC, USA, pp. 808, 831-835, 1113.

14. James SC (1995) Analytical Chemistry of Food. Chapman and Hill Printers London, England, pp. 23.

15. Pearson D (1970) The Chemical Analysis of Foods. ( $7^{\text {th }}$ edn), Churchill Livingstone, London, England, pp. 6-25.

16. Osborne PR, Voogt P (2003) The Analysis of Nutrients in Foods. Academic Press Ltd, London, England, p. 28. 
17. Ayandele A (2015) Microbiological analysis of hawked kunu and zobo drinks within LAUTECH campus, Ogbomoso, Oyo state, Nigeria. IOSRJESTFT 9(10): 52-56.

18. Innocent O, Mariam O, Blessed K (2011) Microbial evaluation and proximate composition of kunu-zaki, an i n d i g e n o u s fermented food drink consumed predominantly in Northern Nigeria. International Journal of Food Safety 13: 93-957.

19. Ameh J, Abubakar A (2002) Microflora of fresh milk and fermented milk product (Nono) in relation to public health in Maiduguri. International Journal of Microbiology 4(1): 14-20.

20. Jablonski L, Bohach G (1997) Food microbiology fundamentals and frontiers, ASM press, Washington DC, USA, pp. 353-375.

21. Oranusi S, Umoh V, Kwaga J (2003) Hazard and critical control points of kunu-zaki, a non-alcoholic beverage in Northern Nigeria. Food Microbiology 20(1): 127-132.
22. Ashiru A, Olaleye O, Egbenni P (2003) Occurrence of pathogenic organisms in kunu drink sold within Lagos metropolis, proceedings of the $27^{\text {th }}$ Annual Nirst conference, pp. 84-87.

23. Umaru G, Tukur I, Adamu N (2014) Microflora of kunu-zaki and zobo drinks in relation to public health in Jalingo metropolis, North-Eastern Nigeria. International Journal of Food Research 1: 16-21.

24. Amusa N, Ashaye O (2009) Effect of processing on nutritional, microbiological and sensory properties of kunu-zaki(a sorghum based non-alcoholic beverage) widely consumed in Nigeria. Pakistan Journal of Nutrition 8(3): 288-292.

25. Prescott LM, Harley JP, Klein DA (2002) Microbiology. (5 $5^{\text {th }}$ edn), McGraw-Hill, London, England, pp. 963-971.

26. Food Agricultural Organisation (1999) Fermentation cereals; A global perspective. FAO Agricultural services Bulletin No. 138

\section{Your next submission with Juniper Publishers will reach you the below assets}

- Quality Editorial service

- Swift Peer Review

- Reprints availability

- E-prints Service

- Manuscript Podcast for convenient understanding

- Global attainment for your research

- Manuscript accessibility in different formats

( Pdf, E-pub, Full Text, Audio)

- Unceasing customer service

Track the below URL for one-step submission https://juniperpublishers.com/online-submission.php 